\title{
INCIDENCE OF HYDROMETRA IN GOATS AND THERAPEUTIC EFFECTS
}

\author{
Tomislav Barna ${ }^{1}$, Jelena Apić1, Dejan Bugarski ${ }^{1}$, Nevena Maksimović2 \\ Aleksandar Mašíc ${ }^{3}$, Zoran Novaković ${ }^{4}$, Aleksandar Milovanovićił \\ ${ }^{1}$ Scientific Veterinary Institute "Novi Sad", Serbia \\ ${ }^{2}$ Institute for Animal Husbandry, Belgrade-Zemun, Serbia \\ ${ }^{3}$ Faculty of Ecological Agriculture, Educons University, Sremska Kamenica \\ ${ }^{4}$ PSS “Novi Sad", Temerinska 131, Novi Sad, Serbia
}

\begin{abstract}
The presence of hydrometra was analyzed on five dairy goat farms (one Saanen and four Alpine) in a period of one to three years, from 2013 to 2016. Total of 3,355 goats were scanned by ultrasound for pregnancy diagnosis after breeding season or out-of-season upon hormonal synchronization. Overall incidence of hydrometra was $1.37 \%$. One farm of Saanen goats demonstrated statistically higher incidence of hydro/pyometra as compared to other four Alpine farms $(3.25 \%$ vs. $0.56 \%$; $p<0.001)$. Seasonal synchronization of anestric goats and occasional out-of-season synchronization in nulliparous Saanen goats probably contributed to higher incidence of this pathological condition $(7 / 67 ; 10.45 \%)$, thus leaving unclear if this results can be attributed to breed affinity and/or to intensive reproductive management. Treatment with double prostaglandin injections and antibiotic treatment of hydrometra/pyometra resulted in relatively good conception rate of $64 \%(16 / 25)$. In conclusion, regular ultrasonography 40-70 days after mating or insemination is of crucial importance for intensive farm reproductive management on large dairy goat farms. After the treatment, significant percentage of goats with hydrometra can be successfully rebred.
\end{abstract}

Key words: goat, reproduction, hydrometra.

\footnotetext{
${ }^{1 *}$ Corresponding author: aca@niv.ns.ac.rs
} 


\title{
ZASTUPLJENOST HIDROMETRE KOD KOZA I EFEKTI TRETMANA
}

\author{
Tomislav Barna ${ }^{1}$, Jelena Apić ${ }^{1}$, Dejan Bugarski ${ }^{1}$, Nevena Maksimović ${ }^{2}$, \\ Aleksandar Mašić ${ }^{3}$, Zoran Novaković ${ }^{4}$, Aleksandar Milovanovićl ${ }^{\prime *}$ \\ ${ }^{1}$ Naučni institut za veterinarstvo „Novi Sad“, Novi Sad \\ ${ }^{2}$ Institut za stočarstvo, Beograd-Zemun \\ ${ }^{3}$ Fakultet za ekološku poljoprivredu, Univerzitet Educons, Sremska Kamenica \\ ${ }^{4}$ PSS “Novi Sad", Temerinska 131, Novi Sad
}

\section{Kratak sadržaj}

Prisustvo hidrometra je analizirano na 5 farmi mlečnih koza u periodu od jedne do tri godine. Ukupno 3.355 koza je skenirano ultrazvukom radi detekcije graviditeta nakon sezone parenja ili van sezone, nakon hormonske sinhronizacije. Ukupna učestalost hidrometra iznosila je 1,37\%. Jedna farma sanskih koza je pokazala statistički veću učestalost hidro/piometre u odnosu na ostale 4 Alpina farme $(3,25 \%$ : 0,56\%; $p<0.001)$. Sezonska sinhronizacija anestričnih koza i povremena vansezonska sinhronizacija nuliparih jarica verovatno je doprinela većoj učestalosti ovog patološkog stanja $(7 / 67 ; 10,45 \%)$, ostavljajući neodređenim da li se ovi rezultati mogu pripisati rasnoj sklonosti ili/i intenzivnom sistemu upravljanja reprodukcijom.Tretman sa dvostrukim injekcijama prostaglandina i antibiotika kod hidrometri/piometri doveo je do relativno dobre stope koncepcije od 64,00\% (16/25). Kao zaključak, redovni ultrazvučni pregled sa 40-70 dana nakon parenja ili oplodnje je od presudnog značaja za intenzivni reproduktivni menadžment u velikim farmama muznih koza. Nakon tretmana, značajan deo koza sa nalazom hidrometre može se uspešno upariti.

Ključne reči: koza, reprodukcija, hidrometra 


\section{INTRODUCTION}

Hydrometra is an important pathological condition in goats and represents one of the main causes of temporary infertility. It occurs mainly in dairy goats and is characterized by excessive accumulation of sterile fluid in the uterus in the absence of fetuses and placentomes associated with persistent corpus luteum (Hesselink, 1993; Wittek et al., 1998). By ultrasonography, it can be seen as non-echogenic fluid compartments separated by thin tissue wallstrabecules (Hesselink and Taverne, 1994). Although Smith (1980) proposed a difference between pseudopregnancy and hydrometra, most authors consider them synonyms (Pieterse and Taverne, 1986; Martel, 2001).

In the pathogenesis of this condition, the presence of fluid is the result, but not the cause of a prolonged progesterone secretion (Taverne et al., 1988), probably due to a failure in the luteolytic mechanism.

According to Brice et al. (2003), two important mechanisms are needed to establish hydrometra: 1) spontaneous persistence of the corpus luteum (CL) after an ovulation without fertilization, and 2) the persistence of the CL after an early embryonic mortality.

According to Chemineau et al. (1999), at least $50 \%$ of the cases of hydrometra in goats occur as a consequence of embryo mortality that apparently takes place at a gestational age of about 40 days (Wittek et al., 1998). Also, it could be linked to indiscriminate use of hormones or mating outside the breeding season (Pugh, 2002). However, this can also be observed in goats with spontaneous or synchronized ovulation, even if they have not been mated (Pieterse and Taverne, 1986; Wittek et al., 1998). Nonetheless, Hesselink and Elvin (1996) identified a genetic influence on its occurrence.

\section{MATERIALS AND METHODS}

In this study, a collection of ultrasound pregnancy control results obtained from five commercial goat milk farms from different locations in the Republic of Serbia in the period 2013-2016 were analyzed in order to determine the incidence of hydrometra. One farm was located in central part of the country, at a latitude 800 meters above sea level. Other farms were located in the flatland, i.e., northern part of Serbia. The goats were kept in an intensive system, in stalls, and fed and milked twice daily. Average production on these five farms ranged from 500 to 850 liters of milk in 280 days of lactation. The animals were between 1 and 8 years of age, mostly with good body condition score (BCS) of 3.5 out of 5 . They were fed various available forages: corn silage, Lucerne 
haylage, hay, soy and wheat straw, concentrates with different balanced formulations fed according to milk production. Drinking water was available ad libitum.

Annual buck fertility control was done before breeding season on two of these farms including clinical tests and semen control after electro-ejaculation. Semen was evaluated by CASA method, flow cytometry (viability test and sperm chromatin structure assay) and cyto-morphology. The number of goats per buck was determined according to breeding value, and then adjusted to scrotal circumference, body condition and semen quality.

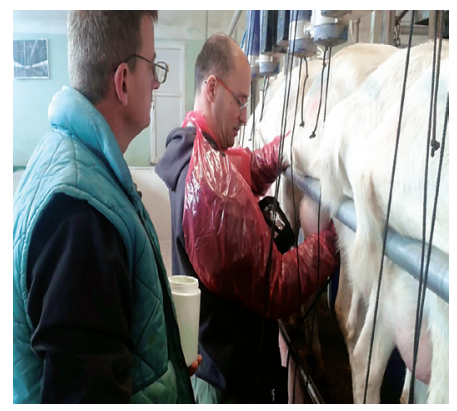

Picture1. Portable ultrasounds facilitate and speed up scanning practice. About 100 animals can be scanned in an hour.

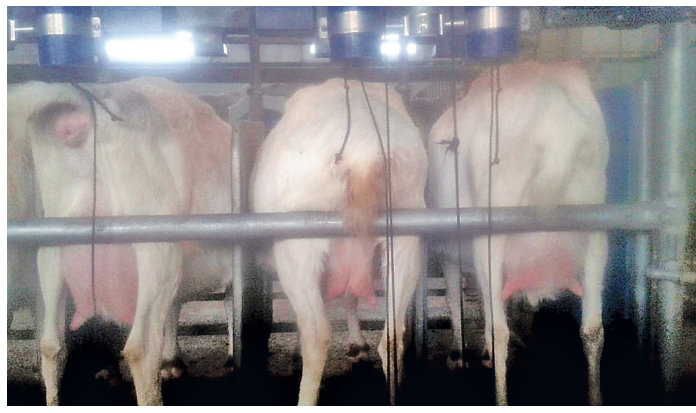

Picture 2. Goats presented to ultrasound check: left pregnant goat with swollen vulva after injury; goat in the middle characterized by dirty tail (vaginal/uterine exudate) are often recognized indicating barren goats with reproductive problems.

All examinations were performed applying a B-mode transrectal ultrasonographic scanner with $5 \mathrm{MHz}$ transducer (WED 3000 Vet Palm hand held veterinary animal ultrasound scanner, WELD, China), 1.5 months after the end of the breeding period. Goats were scanned to determine pregnancy, number of fetuses and its approximate gestation length if no farm-data records were available or to confirm correctness of hand mating dates. At ultrasound control, the does were kept in a standing position. Additional check was done by transrectal scan if no fetuses were diagnosed after transabdominal scanning. Fecal pellets were removed manually (with a gloved, gel-lubricated fingers). The tip of the probe was protruded into the rectum supported with index finger, then pushed through the entire its length and left-right rotation was done to widescan intrapelvic area. Using the rectal control method, pregnancy can be detected as early as 20 days. Up to $5 \%$ of early pregnancies not diagnosed 
at transabdominal check can be detected after transrectal ultrascanning, thus increasing precision of pregnancy diagnosis.

The majority of ultrasound checks for pregnancy were performed in the period November-January (after natural seasonal breeding) or during the May-June period (for out-of-season breeding).

After control, unpregnant animals were segregated according to diagnosed problems and management decision:

- Old goats ( $\geq 6$ lactations) with lower production results or with doubtful prognosis, requiring long recovery period were culled. This group also included goats with udder problems (limps on udders because of nondifferential Corynebacterium infection, inactive mammary glands), bad teeth, lameness, etc.

- Anestric goats were stated as dominant problem (according to strict evidence of hand mating system). The percentage of goats diagnosed at ultrasound check as non-pregnant without obvious reason was 5-7\% of all animals tested;

- Hydrometra was the most prominent reproductive diagnosis among all reproductive disorders visible at ultrascan;

- Cystic ovarian disease or dead fetus (no heart contraction, undulating membranes with flakes) were rare conditions

The protocol for hydrometra treatment included injection of Cloprostenol at the dose of $250 \mu \mathrm{g}$ each, intramuscularly (IM), twice at 11-12 days intervals. Supporting therapy consisted of three injections, two days apart, of Baytril ${ }^{\circ}$ Max (100 mg/ml Enrofloxacin, KVP Pharma, Germany) for hydro-myxo-pyometra and one $5 \mathrm{ml}$ shot of $\mathrm{AD}_{3} \mathrm{E}$ vitamin for all other treated-unpregnant animals.

Anestric goats have been vitaminized 10 days before synchronized with $30 \mathrm{mg}$ flugestone acetate polyurethane vaginal sponges (Synchro-part, Ceva, France) for 11 days. At day 9 after sponging, 400 IU PMSG (Sugonal, VZ Subotica, Serbia) together with $5 \mathrm{mg}$ dinoprost (Enzaprost, Ceva, France) were applied $\mathrm{i} / \mathrm{m}, 48$ hours before sponge removal. Bucks were joined to goats 42 hours after sponge removal and left in group for the next two days.

After the treatment and rebreed, one more ultrasound check was done to confirm the effects of proposed therapy and repeated mating.

Chi-square test was performed to determine statistical significance of the difference between hydrometra incidence in Alpine and Saanen goats. 


\section{RESULTS}

After routine pregnancy diagnosis of 3,355 scanned goats, 46 animals were diagnosed with hydrometra (incidence of 1.37\%). One farm of Saanen goats had statistically higher incidence of hydro/pyometra complex as compared to other four Alpine farms (3.25\% vs. $0.56 \%$; $p<0.001)$ (Table 1$)$.

Table 1. Description of farm breeds, origin, number of scanned and hydrometra "positive" animals

\begin{tabular}{|c|c|c|c|c|c|c|}
\hline $\begin{array}{l}\text { Farm } \\
\text { No. }\end{array}$ & Farm name & Breed & $\begin{array}{l}\text { Origin of } \\
\text { goats }\end{array}$ & $\begin{array}{c}\text { No. of } \\
\text { scanned } \\
\text { goats }\end{array}$ & $\begin{array}{c}\text { No. of } \\
\text { goats } \\
\text { with hy- } \\
\text { drometra }\end{array}$ & $(\%)$ \\
\hline 1. & Farm "A" 2016 & Alpine & Domestic & 320 & 2 & $0.63 \%$ \\
\hline \multirow{2}{*}{2.} & Farm “B” 2016 & \multirow{2}{*}{ Alpine } & \multirow{2}{*}{$\begin{array}{l}\text { Direct import } \\
\quad \text { (France) }\end{array}$} & 750 & 3 & $0.40 \%$ \\
\hline & Farm “B” 2015 & & & 708 & 4 & $0.56 \%$ \\
\hline 3. & Farm “C” 2015 & Alpine & Domestic & 210 & 2 & $0.95 \%$ \\
\hline 4. & Farm “D” 2015 & Alpine & $\begin{array}{c}\text { Direct import } \\
\text { (France) }\end{array}$ & 140 & 1 & $0.71 \%$ \\
\hline \multicolumn{4}{|c|}{ - Total for Alpine goats: } & 2,128 & 12 & $0.56 \%$ \\
\hline \multirow{5}{*}{5.} & Farm “E” 2016 & \multirow{5}{*}{ Saanen } & \multirow{5}{*}{$\begin{array}{c}\text { Direct import } \\
\text { (Austria) }\end{array}$} & 365 & 6 & $1.64 \%$ \\
\hline & Farm “E” 2015 & & & 279 & 6 & $2.15 \%$ \\
\hline & $\begin{array}{c}\text { Farm "E" } 2014 \\
\text { multiparous }\end{array}$ & & & 237 & 4 & $1.69 \%$ \\
\hline & $\begin{array}{c}\text { Farm "E" } 2014 \\
\text { nulliparous }\end{array}$ & & & 86 & 8 & $9.30 \%$ \\
\hline & Farm “E” 2013 & & & 260 & 10 & $3.85 \%$ \\
\hline \multicolumn{4}{|c|}{ - Total for Saanen goats: } & 862 & 28 & $3.25 \%$ \\
\hline \multicolumn{4}{|c|}{ TOTAL for ALL GOATS: } & 3,355 & 46 & $1.37 \%$ \\
\hline
\end{tabular}

As presented in Table 1, the incidence of hydrometra ranged from $0.40 \%$ to $0.95 \%$ in Alpine goats and $1.64 \%$ to $9.30 \%$ in Saanen goats. The highest percentage of hydrometra incidence in Alpine goats was observed in 2015, while on Saanen goat farm nulliparous does had highest hydrometra percentage in 2014. 
Characteristic of hydrometra at scanning was evident by absence of cotyledons, hypo-echogenic fluid accumulation, and straight nets-like hyper-echogenic membranes, undulating in this fluid, with clear or turbid flakes that are slowly circling like clouds (Pictures 3-5.).
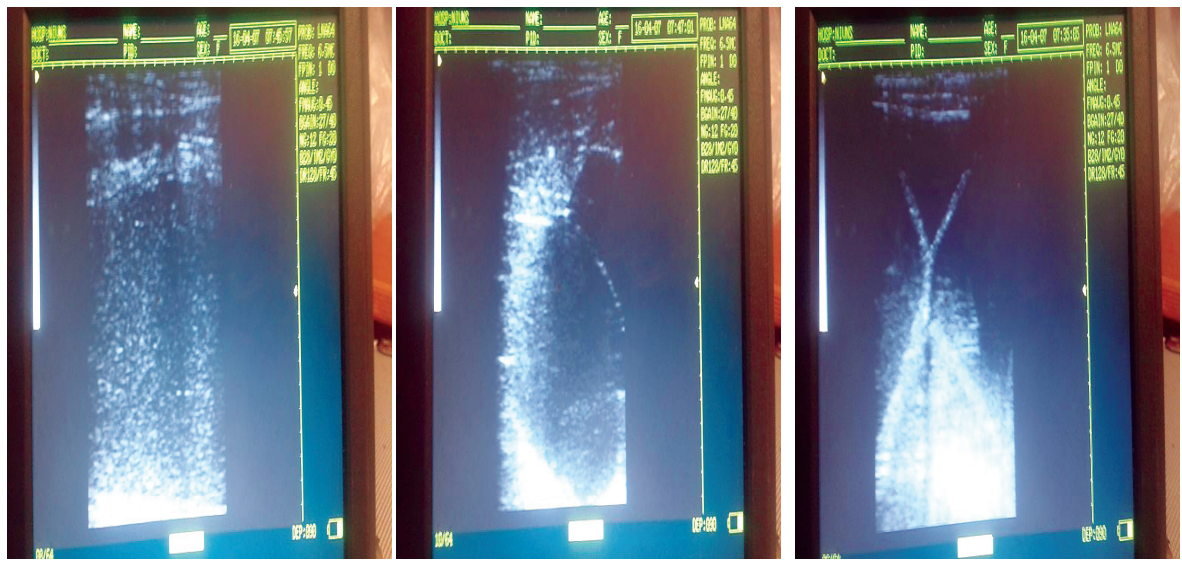

Picture 3 and 4. Pseudopregnancy (hydrometra); the Picture 5. Pseudouterine wall is thin, tensed with clear or slightly turbid fluid, absence of caruncles on fetal membranes.

pregnancy (pyometra); distinctly turbid fluid in uterus.

Treatment with double prostaglandin injections and antibiotic treatment of hydrometra/pyometra resulted in the conception rate of 64\% (16/25) (Table 2).

Table 2. Results of prostaglandin + antibiotic treatment in animals with hydrometra

\begin{tabular}{|c|c|c|c|}
\hline Treatment & $\begin{array}{c}\text { No. of } \\
\text { hydrometra cases }\end{array}$ & $\begin{array}{c}\text { No. of treated } \\
\text { animals }\end{array}$ & $\begin{array}{c}\text { Conception } \\
\text { rate, } \%\end{array}$ \\
\hline $\begin{array}{c}\text { Prostaglandin } \\
\text { +antibiotic }\end{array}$ & 40 & 25 & $64 \%(16 / 25)$ \\
\hline
\end{tabular}

At the end of breeding season, overall annual conception rate is achieved in $88-90 \%$ of goats (ranging from $79.32 \%$ to $95.66 \%$ ).

\section{DISCUSSION}

The diagnosis of hydrometra and other genital conditions in unpregnant animals (cystic ovarian disease, enlarged uterus indicating on endometritis) 
can be routinely determined by ultra sound scanning by experienced practitioner. Animals manifested with fluid in the uterine lumen in the absence of fetuses and placentomes were diagnosed with hydrometra. This condition was recognized by hypo-echoic fluid accumulation. Often, no cases of fetus skeleton were diagnosed by ultra scanning. More frequently, we noticed hyperechogenic mass on the bottom of uterus, if any other structure that indicate the presence of a dead fetus.

The prevalence of pseudopregnancy widely ranges by different authors. Lyngset (1968) reported three cases after examination of 1,020 reproductive tracts at a slaughter house (0.3\%). Holdsworth and Davis (1978) found four animals after 98 checks (4\%). A large investigation in France that included over 10000 she-goats revealed the incidence of the disorder ranging between 2 and $3 \%$ of the females and spread over $>55 \%$ of the flocks. However, the incidence was $>5 \%$ in $11 \%$ of flocks. Significantly higher number of pseudopregnancy cases was observed in out-of-season goats after kidding in autumn and in goats subjected to hormonal treatments for synchronization of estrus (Duquesnel et al., 1992).

Hesselink (1993) found up to 9\% of pseudo-pregnancies on 3 farms in Netherlands, and in some A.I. groups, pseudo-pregnancy may reach even $20.8 \%$. Lopes Junior et al. (2004) reported an incidence of up to 30\% in Saanen dairy goats raised in Northeast Brazil. Similar to our investigation, Wittek et al. (1997) scanned a larger group of animals (2,434 goats) using transrectal ultrasonography throughout the period of three years. The mean incidence of hydrometra was determined to be $5.78 \%$

In our study, an overall incidence of hydrometra was $1.37 \%$, which is lower as compared with the majority of authors particularly when speaking of Alpino milking goats, where the number of scanned animals is more relevant as it included data from 4 different farms with 2,128 checked animals and only 12 cases of hydrometra (0.56\%).

Higher incidence in Saanen breed can be expected to be related to genetic influence (breed) compared to Alpino herds (3.25\% compared to $0.56 \%$, respectively), as this is diagnosed almost 6 times more often. Breed affinity is discussed to some extent by Duquesnel et al. (1992) in a study on a large animal population after 2 consecutive years, yet without any specific conclusion. This can also be attributed to intensive farm management within breeding season or out-of-season hormonal synchronization and keeping older animals in stalls for genetic reason.

As described in the article of Milovanovic et al. (2016), a group of 47 nulliparous Saanen goats that did not show signs of heat were subjected to hor- 
monal synchronization and 37 were mated, resulting with 27 pregnant goats (pregnancy rate of 57.45\%); however, the presence of high percentage of hydrometra and pyometra complex in nulliparous goats in this study was obvious (7 (10.45\%) goats were diagnosed with hydro/pyo-metra at pregnancy check). Ultrasound check of goats was not performed before sponging or breeding season, so, initial prevalence of pseudopregnancy remained unknown.

Hormonal treatment protocol with double prostaglandin injections 11 days apart and antibiotic treatment of hydrometra/pyometra complex was satisfactory therapy and resulted in conception rate of $64.00 \%(16 / 25)$. Salles and Araújo (2008) treated dairy goats with a single dose of PGF and demonstrated that it was sufficient to induce uterus drainage in all animals. Moraes et al. (2007) observed that all female goats $(\mathrm{n}=11)$ diagnosed with hydrometra and treated with PGF showed estrus within $120 \mathrm{~h}$, were mated and were positive for pregnancy after 30 days. Conversely, goats treated with PGF and then subjected to artificial insemination had an average fertility rate of $48 \%$, that is, lower than $73 \%$ obtained in goats without hydrometra in the same herds (Leboeuf et al., 1998). Hesselink (1993) cited that reproductive performance improves when a second treatment is applied. After the first PGF, only 3 out of 20 does conceived but, after the second dose administered 12 days later, 14 out of 29 became pregnant. It is believed that if the disorder is maintained for a long time it could irrevocably damage the endometrium, possibly altering uterus capacity for hormone secretion and leading to subfertility in affected goats. The possibility of using consecutive services with higher interval from the end of the treatment could improve pregnancy rate (Wittek et al., 1997). In the article of Reddy et al. (2014), a total of 20 hydrometra cases were diagnosed, while 18/20 goats exhibited estrus within 2-5 days after second injection of Cloprostenol, and 14 out of 18 estrus goats become pregnant after breeding.

Spontaneous recovery is possible (after hormonal treatment, high producing goats that were not pregnant in this year got pregnant in the next breeding season), if the farmers are willing to keep them without milking for the next breeding cycle (aimed at obtaining progeny from mothers with good milking genetics). Four goats spontaneously recovered in the next breeding season and got pregnant.

\section{CONCLUSION}

Regular ultrasonography is of crucial importance for intensive farm reproductive management in large dairy goat farming.

Average incidence on of hydrometra on five farms in a period of one to 
three years was $1.37 \%$ after scanning 3,355 goats for pregnancy diagnosis after breeding season or out-of-season hormonal synchronization.

Six-time higher incidence was observed on a farm of Saanen goats as compared with the other four Alpine goat farms (3.25\% vs. 0.56\%), but this can be attributed also to intensive farm management with synchronization and keeping older animals in stalls for genetic reasons.

Out-of-season synchronization in primiparous goats probably leads to higher incidence of this pathologic condition.

\section{ACKNOWLEDGEMENT}

This paper is published as part of the projects of the Ministry of Education, Science and Technological Development of Republic of Serbia No. 31050.

\section{REFERENCES}

1. Brice G., Broqua C., Leboeuf B.: La pseudogestation chez la chèvre laitière [Pseudopregnancy in dairy goats]. Point Veterinaire, 34, 50-52, 2003.

2. Chemineau P., Baril G., Leboeuf B., Maurel M.C., Roy F., Pellicer-Rubio M., Malpaux B., Cognié Y.: Implications of recent advances in reproductive physiology for reproductive management of goats. Journal of Reproduction and Fertility. Supplement, 54, 129-142, 1999.

3. Duquesnel R., Parisot D., Pirot G., Mialot J., Saboureau L., Étienne P., Delaval J., Guéraud J.M., Prengere E., de Montigny G., Guerrault P., Perrin G., Humblot P., de Fontaubert Y., Chemineau P.: La pseudogestation chez la ch 'evre. Annales de zootechnie, INRA/EDP Sciences, 41, 3/4, 407-415, 1992.

4. Hesselink J.W.: Hydrometra in dairy goat: Reproductive performance after treatment with prostaglandins. Veterinary Record, 133: 186-187, 1993.

5. Hesselink J.W.: Incidence of Hydrometra in dairy goats. Veterinary record, 132, 110-112, 1993.

6. Hesselink J.W., Elvin L.: Pedigree analysis in a herd of dairy goats with respect to the incidence of hydrometra. The Veterinary Quarterly, 18, 24-25, 1996.

7. Hesselink J.W., Taverne M.A.M.: Ultrassonography of the uterus of the goat. The Veterinary Quarterly, 16, 41-45, 1994.

8. Holdsworth R.J., Davis J.: Measurement of progesterone on goats milk: an early pregnancy test. Veterinary Record, 105, 535, 1979.

9. Leboeuf B., Manfredi E., Boue P., Piacère A., Brice G., Baril G., Broqua C., Humblot P., Terqui M.: Artificial insemination of dairy goats in France. Livestock Production Science, 55, 193-203, 1998. 
10. Lopes Junior E.S., Cruz J.F., Teixeira D.I.A., Lima Verde J.B., Paula N.R.O., Rondina D., Freitas V.J.F.: Pseudopregnancy in Saanen goats (Capra hircus) raised in Northeast Brazil. Veterinary Research Communications, 28, 119-125, 2004.

11. Lyngset O.: Studies on reproduction in the goat. V. Pathological conditions and malformations of the genital organs of the goat. Acta Veterinaria Scandinavica, 2, 364-375, 1968.

12. Martel J.L.M.: Incidencia de la hidrómetra en la agrupación caprina canaria [Incidence of hydrometra in a group of Canarian goats]. Vector Plus, 6, 28-34, 2001.

13. Milovanović A., Barna T., Apić J., Bugarski D., Maksimović N., Jović Ž.: Results of out-of-season breeding in nulliparous saanen goats. The International Symposium on Animal Science (ISAS) 2016, 24-25th November, Belgrade, Serbia, [editor in chief Zoran Popović], Proceedings, 61-68, Zemun, Faculty of Agriculture, 2016

14. Moraes E.P.B.X., Santos M.H.B., Arruda I.J., Bezerra F.Q.G., Aguiar Filho C.R., Neves J.P., Lima P.F., Oliveira M.A.L.: Hydrometra and mucometra in goats diagnosed by ultrasound and treated with PGF2a. Med. Vet., 1, 33-39, 2007.

15. Pieterse M.C., Taverne M.A.M.: Hydrometra in goats: diagnosis with realtime ultrasound and treatment with prostaglandins or oxytocin. Theriogenology, 26, 813-821, 1986.

16. Pugh D.G.: Sheep \& Goat Medicine, first ed. Saunders, Philadelphia, 2002.

17. Reddy K.R.C., Rao K.S., Reddy K.C.S., Murali Mohan K., Ram Singh L.: Treatment of hydrometra in does by using cloprostenol. Proceeding of XXVII annual convention of ISSAR. p. 36. Held at CVSc, CAU, Aizawl, Mizoram, 2011.

18. Salles M.G.F., Araújo A.A.: Pseudogestac, ão em cabras leiteiras - Relato de Caso [Pseudopregnancy in milk goat: case report]. Vet. Zootec, 15, 251-256, 2008.

19. Smith M.C.: Caprine production. In: Morrow, D.A. (Ed.), Current Therapy in Theriogenology: Diagnosis, Treatment and Prevention of Reproductive Diseases in Animals. Saunders, Philadelphia, 969-1004, 1980.

20. Taverne M.A.M., Lavoir M.C., Bevers M.M., Pieterse M.C., Dieleman S.J.: Peripheral plasma prolactin and progesterone levels in pseudopregnant goats during bromocrytine treatment. Theriogenology, 30, 777-78, 1988.

21. Wittek T., Erices J., Elze K.: Histology of the endometrium, clinical-chemical parameters of the uterine fluid and blood plasma concentrations of progesterone estradiol $17 \beta$ and prolactin during hydrometra in goats. 
Small Ruminant Research, 30, 105-112, 1998.

22. Wittek T., Richter A., Erices J., Eelze K.: Incidence, diagnosis, therapy and subsequent fertility in goats with hydrometra. Tierärztliche Praxis Großtiere, 25, 576-582, 1997.

Primljeno: 01.03.2017. Odobreno: 10.06.2017 